Saudi Journal of Business and Management Studies Abbreviated Key Title: Saudi J Bus Manag Stud ISSN 2415-6663 (Print) |ISSN 2415-6671 (Online) Scholars Middle East Publishers, Dubai, United Arab Emirates Journal homepage: https://saudijournals.com/sjbms

Original Research Article

\title{
Management of Capital Availability on Shareholding Ratio and Business Performance
}

\author{
Zhang Yong $\mathrm{An}^{1^{* *}}$, Aasma Memon ${ }^{1}$, Muhammad Qasim Memon ${ }^{2}$, Abdul Rehman Memon ${ }^{3}$, Muhammad Jaffar ${ }^{4}$ \\ ${ }^{1}$ School of Economics and Management, Beijing University of Technology, Beijing 100124, China \\ ${ }^{2}$ Advanced Innovation Center for Future Education, Faculty of Education, Beijing Normal University, Beijing, China \\ ${ }^{3}$ Department of Chemical Engineering, Mehran University of Engineering \& Technology, Jamshoro, Sindh, Pakistan \\ ${ }^{4}$ Department of Civil Engineering, Mehran University of Engineering \& Technology, Shaheed Zulfiqar Ali Bhutto Campus, Khairpur Mirs', Sindh, \\ Pakistan
}

DOI: $10.36348 /$ sjbms.2020.v05i06.002

| Received: 25.05.2020 | Accepted: 06.06.2020 | Published: 11.06.2020

*Corresponding author: Zhang Yong An

\section{Abstract}

Demand of business performance enlargement is expeditiously increasing and its achievement is an important concern in the contemplation of management capability and domestic enterprises. Corporate governance mechanism is a big controversy to this concern and it became a conventional research in every country and their relation with executive is different due to the law and proprietary structure. In this article, executive' shareholding impact on business performance is evaluated in order to analyze the executive ownership concentration and their relationship with business performance. Moreover, analysis is performed using theoretical and empirical method to control over business performance. First, theoretical method is considered to analyze co-relationship between executive and corporate performance and its significance to the business performance. Second, empirical method evolved with underlying measurement models and evaluated using regression analysis and robustness test. We collected the data of Chinese listed companies (partitioned into state and non-state owned companies) in the year from 2014 to 2016 . Empirical results could find a positive correlation between executive and corporate performance as well as validating the improvised hypothesis. We also found that executive ownership could guide and impel the management to alienate the interests of executives' shareholding ratio in order to shorten the interim behavior of senior executives. Our findings provide more insights on executive ownership to expedite business performance management by straightening the interests of executives.

Keywords: Executive shareholding, corporate performance, Executive holding, Empirical analysis, corporate governance, ROA.

Copyright @ 2020: This is an open-access article distributed under the terms of the Creative Commons Attribution license which permits unrestricted use, distribution, and reproduction in any medium for non-commercial use (NonCommercial, or CC-BY-NC) provided the original author and source are credited.

\section{INTRODUCTION}

Advancement of effectuality and efficient corporate governance become a serious agendum to enhance business in developing countries in order to promote managerial magnificence and a delicate governance structure to business [1]. Economists and social scientists explained the concept of corporate governance extensively such as governing bodies manipulating business could generate resources and returns [2]. Similarly, concept for corporate governance is presented in terms of assuring business, its management and investors in the pursuance of an impressive return [3]. These distinctive concepts in the shape of phrases determine the importance of formal guidance for organization's corporate governance. However, these phrases also discourage the catastrophic of an informal system arrangement that could proceed upward in the absence of formal rules [4]. In addition, these definitions illustrate internal structure and expatiate interaction with external mechanism of the business. Currently, corporate governance is a big contention in the business world and conventional approach found by different studies for China [5-6]. However, it is difficult to find out the best one [7]. Corporate governance deals with company law, proprietary structure and its main concern lies in the agency problem describing the separation of 
management and finance [8]. This separation concept refers to managers such as to hire a chief executive officer (CEO) with higher skills and abilities [9], where responsible pillars of the company such as proprietor and different stakeholders hire the CEO. According to international standards [10], enterprises are hiring professionals with high management skills in order to rectify the company's enhancement and goal. Since, CEO is not the owner of the business. This implies the phenomenon to operate the company and indifference of ownership. Therefore, emergence of this phenomenon could be inevitable in order to modernize business management.

Conversely, there are many concerns involved from the incentive of executive ownership to the advancement of economy in order to reform the management system of a company [11]. Companies are required to allocate the structure of corporate governance, wherein managers receive enough incentives. Although, managers receive incomplete incentives and hence company is authorized to put them back and take possible replacement. However, senior managers are likely to get personal income and responsible for abusing the stock options deflecting from the original expectations of the incentives [12]. With the rapid development of China's economy and business world, the internal and external environment of companies become more complex and diverse. Therefore, company requires professional managers [13]. Since, owner and manager could not be the same person [14]. Corporate governance is applied narrowly to interrogate about the structure and responsibilities of boards of directors such as their management in decision-making, shareholders' rights, interests and privileges. On the contrary, business owner is responsible for exploring new strategies to accomplish business challenges and tasks, wherein managers could strive to solve afore-mentioned concerns in order to derive the company management at the owner's expectations and directions.

The emergence of equity system can effectively solve these concerns [15]. Equity theory preserves an affiliation between an employee's motivation and his/ her apprehension to equity or inequity direction. For example, China Securities Regulatory Commission (CSRC) promulgated the relevant management methods of equity incentive. CSRC provided the policy guidance for the business in 2005 [16]. In 2006, China Ministry of Finance and the State-owned Assets Supervision and Administration Commission (SASAC) promulgated the methods of managing the equity incentive of state-owned listed companies [17]. The promulgation of these systems eradicated the obstacles toward implementation of equity incentive system in China and allowed domestic enterprises to make the normal operation of enterprises. In 2010 and 2011, China introduced a small board listed on the GEM (Growth Enterprise Market), where listed companies were required to implement the equity incentive methods [18]. Meanwhile, Chinese stateowned allocation is still governing on the proprietary rights in different listed companies. This contrive could doubt on capability and effectiveness on privatization of Chinese firms to re-explore and their aspects on listed companies in the furtherance to align the executive and corporate performance.

Existing studies [19-21] were presented on executive and corporate performance in developed countries such as United States, Great Britain, Japan, Germany, China and France. Our investigation on CEO ownership and corporate performance in the Chinese listed companies is consisting of both empirical and theoretical analysis. However, relationship between proprietary rights of corporate governance and corporate performance is analyzed based on the theoretical analysis rather using an empirical research [22]. Thus, less analysis conducted on a one-to-one relationship of CEO and corporate performance. The relationship between proprietary rights of an executive and corporate performance based on our investigation present the improvements in the governance structure of the company, maintenance of shareholder's rights and their interests, enhancing the competitiveness, ensuring the rapid and effective operation of the company. In addition, empirical results of the present study would be helpful for the future assessment in the area exist between executive ownership and corporate performance. The present study also superior to those who claim that the executive ownership has negative relationship with corporate performance [19]. In our investigation, empirical analysis transpires positive relationship of executive ownership towards business and its better enhancement in the Chinese listed companies. Since, international market and financial environment are becoming more complex due to financial stakeholders with an extant empirical declaration of corporate governance system encouraging shareholders interest [23]. This resulted normal operation of the company considering the owner's right and economic development needs for corporate governance and contradiction could appear between senior manager and owner that could be harmful for the business achievement [24]. The governance of the company could be attentive about business in order to strengthen the internal and external governance mechanism. While, executive holding is one of the best means to motivate senior managers and thus improving their competitiveness.

The objective of this investigation is to emphasize afore-mentioned concerns and introducing the definition of executive shareholding ratio and corporate performance. Moreover, the relationship between proprietary rights of an executive ownership and corporate performance is conducted on Chinese listed companies using motherboard data (in the year from 2014 to 2016). Further, an intrinsic mechanism of 
the executive stock ownership and company performance could transpire the shareholders' relation with business and their performances. In general, our investigation is based on the following contributions:

- Enrich the analysis on the relationship between ownership rights of an executive and corporate performance in Chinese listed companies.

- This study is of great significance that could improve the corporate governance structure of the company, maintenance of shareholders rights and interests.

- Relationship between ownership rights of an executive and corporate performance could provide the operable suggestion for further perfecting the enterprise governance system.

The rest of the article is organized as follows: Section 2 describes existing literature conducted in domestic and foreign countries. Section 3 present hypotheses development used in theoretical analysis. Section 4 present data sample and measurement variables used in the empirical analysis. Section 5 shows empirical results based on regression model and robustness test. Section 6 draws the concluding remarks. Section 6 presents the implications of the present study. In the final section, future work and limitations are discussed.

\section{LITERATURE REVIEW \\ Chief Executive Officer (CEO) status}

Existing studies [25-26] suggested the separation of CEO and chairperson of the board resulted in number of business problems when the CEO is also the chairperson. For example, corporate performance is either positively related with an intercession of management in terms of member' selection board or negatively related with executive being the chairperson of the board [21, 27]. Similarly, a study conducted in [28] on 452 firms, which showed corporate performance is higher when the executive, owner, board of directors and chairperson positions are inhabited by different persons.

\section{Principal-agent theory}

Principal-agent theory is a necessary part of the company's operations. The earliest study of the principal-agent theory was suggested in [29], which describe principal and agent have a conflict of interests in case of asymmetric information. The conflict of interests between principal-agent based on four typical issues: First, capability of antipathy efforts. Second, agent can use his/her work efforts increasing his own personal benefits. Third, different opinions of agent and principal for their semi-permanent relationship could occur. Fourth, dissimilar affectation from manager and principal could create risks in business. In addition, principle agent theory dealt with several issues in business when there is conflict of interests between principal and agent [23]. The main concern of the principal-agent theory is when one party assigns work (duties) to another party. These two parties referred as principal and agent. In other words, principal is the owner/shareholder of a company and agents are the managers, wherein, owners hire managers to enhance the performance of the business rendering impressive return for the business [30]. Moreover, owner should keep their interests aligned with their agents in order to avoid the business risks and reducing agency problems such as improving directors, keep an eye on managers, control on the pixilated behavior of managers and agent equity ownership [26, 31]. Although, there is need to establish and implement incentive mechanism to deal with the business risks and contradictions between principal and the managers. This mechanism was implemented in [32] to increase power of managers and $\mathrm{CEO}$, which could impose positive impact on corporate performance in order to achieve desired goal effectively. However, when owner could not arrange an appropriate aforementioned incentive mechanism for mangers resulted in poor corporate performance.

\section{Incentive theory}

Incentive theory enables to achieve targets easily for business. It mobilizes the enthusiasm of participation and ultimately creates the realization of goal in employees [33]. However, employees consider it like a pledge. In business incentive theory, there are two main goals to motivate an employee to work in an improvised manner. First, it is an additive benefit and compensation for an employee. Second, incentive enables employees to recognize his/her achievements for better performances [2]. Moreover, incentive theory is more representative of expectation theory, two-factor theory and demand hierarchy theory. According to analysis of human behavior, people estimate results before they take action and when these estimated results are in line with their expectations, they act with a strong driving force. On the contrary, when estimated results do not meet with their expectations, people may not take measures or even take the opposite actions. Therefore, incentives play a vital role in corporate performance to achieve the goal of stimulating expectations in business [34-36]. Meanwhile, representative of the two-factor theory was presented by Hertzberg [37-38], which is based on health and motivating factors on incentives for people satisfaction in an organization. The incentive factor is the ability to motivate the actions of employees and lack of incentives, which could produce unsatisfactory circumstances such as incentives including sense of accomplishment, sense of responsibility, good job performance and promotion opportunities for peoples. On the other hand, representative of demand hierarchy theory was presented by Maslow [39], which describes human needs are hierarchical and they are in order shape, wherein order cannot be crossed. In addition, these needs are divided into four levels such as security, social, respect, and self-realization. The lower level need required fewer difficulties to change the external 
conditions and this level is possible to achieve. While, remaining three levels are on the higher requirements and can be achieved through the improvement of internal conditions such as level of satisfaction and incentive.

\section{Corporate governance theory}

Corporate governance is a system to guide and control the effective operation of the company. Currently, research of corporate governance mainly involves organization's design and legislation, rights and obligations of each participant by means of contract [40]. Since, corporate governance is divided into internal and external governance model and achievable once it is implemented [5]. The core issue of corporate governance is well-run corporate governance mechanism, where theory of internal checks and balances belong to the narrow area of corporate governance. Corporate governance mechanism is mainly related with the relationship between shareholders and the company, management and shareholders, and among shareholders. Although, corporate governance is a key indicator of business performances and principal-agent theory depends on the agent's ability and effort. Moreover, business managers in the company and external environment play a decisive factor in the business. Therefore, quality of good business management and efforts of managers are inseparable. In the modern enterprise system, management rights and ownership are separated. However, manager's efforts and ability is related to the performance of the business. Since, the ability to do more and pay the greatest efforts of managers does not necessarily lead to the maximization of corporate performance [41]. Thus, companies with internal and external governance organic integration could achieve the goal of corporate governance and its expected performance. For instance, existing studies were concluded affirmation of good corporate governance that resulted more advancement in a legitimate competitive position [42].

\section{Theoretical hypotheses development Impact of CEO on the corporate performance}

The concept of executive is considered a major role in particular to handle corporate governance mechanism in china [43]. In management, liberty is explained as the self-determination of executive or manager. Executive's liberty is essential to deal with decision-making power to enhance the corporate performance and explores the effectuality of executive [44]. In contemporary companies, executive's rights are detachment from ownership. This detachment of proprietorship and control in enterprises generate the possibility of variance of interest between executive and shareholders in order to develop the information asymmetry. Meanwhile, executives should possess the proficiency skills in management to deal with current market competitive circumstances and their decisions must provide quick response towards the apace- dynamical environment. Hence, company must provide an impressive compensation for executives. In addition, theory of proprietary rights explores executives as the important pillar of the company and enhance the corporate performances. Moreover, proprietary rights theory insisted to use their stock options (shares) and long-term incentives to maintain the company's residual claims rather manipulating the appropriate business risks based on solely short-term incentives such as raising basic wages, performance bonuses, and annual compensation to stimulate executive motivation and enthusiasm.

In Chinese listed companies, internal management increasingly grown-up and external environment is comparatively reliable too [45]. Stockholders are well aware from their duties and actions to handle with the operating activities of the companies. Therefore, it is not necessary to handover more decision making powers to executives. However, Chinese listed companies are rapidly applying current developed technologies and facing the competition environment of rapid changing in market [46]. In accordance with such complicated and extremely uncertain environment, shareholders are not distinctly aware about the right or wrong strategies and speculation projects. This invigilation could highly effect on the company performance. Thus, two hypotheses are formulated based on aforementioned theoretical analysis.

H1: Executive discretion has positive impact on corporate performance.

$\mathrm{H} 2$ : Executive discretion is negatively correlated with corporate performance in Chinese listed companies.

\section{CEO, shareholder and corporate performance}

Principal-agent theory is based on two fundamental notions derived from institutional behavior and economics [47]. First, public choice theorists believe that self-interests drive (rational utility maximizes) the behaviors of people and their organizations. Second, as a result of rational utility maximizes, all non-state owned and organizational activities determine the relationships among parties, individuals and organization. Relationship between board independence, ownership structure and their performances suggested that shareholders are negatively related to the corporate performance [48]. Meanwhile, two conclusions were derived on relationship between corporate and executive [49]. First, there is a positive relationship between corporation size and executive compensation. Second, there is a negative relationship between executive and firm performance. On the contrary, corporate performance is affiliated positively with the intermediation of management in terms of selection of board members [50]. Therefore, fewer agency complications occur when the owner, director and executive are not the same persons [51]. However, scholars reported that there is no significant relationship 
between executive ownership and corporate performance [52].

Similarly, proportion of executives holding less than $40 \%$ indicated a positive relationship with corporate performance, and 40\%-50\% shareholding indicated a negative relationship. Relationship between the concentrations of equity presented in [53] showed no significant relationship between executive shareholding and corporate performance. Whereas, relationship between CEO pay and firm performance was reported relatively positive [54]. Moreover, a research presented in [32] suggested a positive and probative relationship between CEO compensation and firm performance, where compensation is measured using return on assets. A research conducted on $414 \mathrm{UK}$ listed companies [55] concluded a correlation between corporate performance and CEO ownership leveraging the right incentive toward CEO in order to align with managers and shareholders interest. Based on above theoretical analysis, present study offers the following hypothesis:

H3: shareholders are positively related with corporate performance.

\section{Relationship between executive compensation and corporate performance}

In recent decades, executive compensation is receiving much attention and became a highly focused debate in organizational governance, where managers possess outstanding control on the company and its operations [56]. When a company appears to a failure or weak organizational governance exist, it appears due to the lack of interest of managers [52]. In order to overcome above-mentioned failure, a company should pay an impressive amount or compensation to executives. Therefore, executive compensation getting positive effects on corporate performance. When performance of a company is accumulated, executive compensation will also be increased. Principally, executive compensation and corporate profitability are concerned with each other.

$\mathrm{H} 4$ : CEO pay is positively related with corporate performance

\section{Theoretical conclusion}

Firm's performance depends upon on the relationship between bodies in business such as executives and stockholder, stockholder and managers, and debt holder and stockholders. Due to crash between interests of these bodies, their relationship become worse resulting an impact on corporate governance through ethical decisions of business and management. According to the corporate governance [57], there is a link between firm performance and proprietary or structure of boards of directors. A positive relation between CEO and corporate performance could pay a high salary to their CEOs in order to facilitate and motivate them to work harder and improving the firm's performance [33]. A negative correlation between executive ownership and corporate performance using empirical research [58] showed no significant relation between CEO ownership and corporate performance due to historical and sociological factors such as small capital and less interest of managerial ownership increasing day-by-day risks in business and market development. Therefore, CEO remuneration plays an important role in business performance. The aforementioned empirical research reported different conclusions due to the small number of samples taken or scope of the study was limited and disclosure of information was not sufficient. In addition, incentive mechanism of stock and difference between reforms of non-tradable shares could impart to different conclusions of the research. Hence, results were presented with inconsistent conclusions. The reasons for discrepancies among conclusions are as follows:

First, different caliber of statistical data. Second, differences in statistical definitions of same variables. For example, different definitions of management scope such as CEO of the company, board members, and supervisory board stimulate different results. Third, definition of shareholding ratio was ambiguous such as holding the company's ownership ratio, company's market capitalization ratio, and both company's ownership and market ratio with their difference in the metrics of corporate performance. Fourth, selection and calculation of these indexes such as Tobin $\mathrm{Q}$ value, total asset return rate, net assets return rate, earnings per share and net assets per share. Existing studies were conducted a lot of in-depth research on executive stock and company performance. However, conclusions are not uniform and most of them biased to industry-wide research. While, focus on a particular industry is very small in comparison to the prominence of listed companies in China [5, 18]. Therefore, ambition of this investigation is to conduct both theoretical and empirical analysis of relationship between executive shareholding and corporate performance in the listed companies of China.

\section{RESEARCH DESIGN Sample selection}

Sample selection is selected from listed companies of China during the period from 2014-2016. A total number of 280 companies were selected initially. However, number of companies eliminated from the sample selection due to the unavailability and missing data. Finally, total number of sample is 165 and selected sample is divided into state-owned companies (SOC) and non-state-owned companies (N-SOC). The total SOC sample is 24 and N-SOC sample is 141. Executive data compensation and shareholdings are taken from annual reports and Wind database. Moreover, these annual reports contain corporate data of board and governance structure published by China Security Regularity Commission (CSRC). Wind database composed of economic terminal and financial 
database categorized in Shanghai Stock Exchange (SSE) and Shenzhen Stock Exchange (SZSE) pertaining data on Chinese listed companies such as capital structure, corporate governance, fundamental, pricing, and ownership data.

\section{Variable design}

Description of variables and their calculation methods are given in Table 1. ROA describe profitable percentage of a company relative to its assets and evaluates the capability of increasing profit of a company before taking its own capital assets. Higher value of ROA transpire a good profitability of a business. Company owner and large shareholders contain greater allocation of resources than small shareholders and good relationship directly influences the performance of enterprises. Hence, TOP1 chosen as control variable. TOP10 reflects the degree of checks and balances among shareholders when lack of balance between the shareholders is identified. CFR proportion is produced from business activities and produce an impact on firm's performance. LEV is the total amount of liabilities over the total assets of a company's asset structure that affects the performance of the entire company and hence, LEV is chosen as control variable. $\mathrm{QR}$ is chosen as control variable, which is ratio of quick assets to current liabilities. This index has the ability to measure current assets of an enterprise. According to the general experience, current ratio more than $200 \%$ has a strong solvency for company's production, thereby, affecting the performance of the enterprise. Operate is the natural logarithm of total days of inventory turnover and sum of the receivable turnover that represent the operation ability and performance of an enterprise. Therefore, Operate is control variable. SIZE is the natural logarithm of total assets at the beginning of the period. Moreover, natural logarithm of total assets is selected to measure the overall size of the company and selected as control variable. TAT is the net amount of business income compared to the average total assets. Greater the turnover rate, faster the total assets turnover that provide stronger sales ability. TAT is selected as control variable. EPS is the total number of shares and net profit of a company owned by a common stockholder. It compromises net profit or bear net loss of the enterprise. Thus, business performance and earnings per share are correlated positively. Therefore, EPS is selected as control variable.

Table-1: Description of variables and their calculation method

\begin{tabular}{|c|c|c|c|}
\hline Variable name & $\begin{array}{l}\text { Variable } \\
\text { symbol }\end{array}$ & Type of variable & calculation method \\
\hline $\begin{array}{l}\text { Total net profit/Return on } \\
\text { assets }\end{array}$ & ROA & $\begin{array}{l}\text { Dependent } \\
\text { variable }\end{array}$ & Net profit / average total assets \\
\hline Executives holding shares & MO & $\begin{array}{l}\text { Independent } \\
\text { variable }\end{array}$ & executives holdings / total share capital \\
\hline $\begin{array}{l}\text { The largest shareholder of } \\
\text { the shareholding ratio }\end{array}$ & TOP 1 & Control variable & the largest shareholder holdings / total share capital \\
\hline $\begin{array}{l}\text { The top ten shareholders } \\
\text { holding the proportion }\end{array}$ & TOP 10 & Control variable & $\begin{array}{l}\text { the top ten shareholders share the sum of the total } \\
\text { share capital }\end{array}$ \\
\hline $\begin{array}{l}\text { Cash flow ratio from } \\
\text { operating activities }\end{array}$ & $\mathrm{CFO}$ & Control variable & $\begin{array}{c}\text { Net cash flow from operating activities / operating } \\
\text { income }\end{array}$ \\
\hline Asset-liability ratio & LEV & Control variable & $\begin{array}{l}\text { Total debt at the end of the period / Total assets at the } \\
\text { end of the period and measure the company's financial } \\
\text { risk }\end{array}$ \\
\hline Quick moving ratio & QR & Control variable & quick assets / current liabilities \\
\hline Operating cycle & Operate & Control variable & $\begin{array}{c}\text { Ln (inventory turnover days }+ \text { accounts receivable } \\
\text { turnover days) }\end{array}$ \\
\hline Company size & SIZE & Control variable & Ln (beginning of total assets) \\
\hline Total Assets Turnover & TAT & Control variable & Net Operating Income / Average Assets \\
\hline Earnings per share & EPS & Control variable & Net profit / total number of shares \\
\hline
\end{tabular}

Model

The theoretical and empirical framework shown in Figure 1, empirical analysis is based on the following measurement models are given, respectively.

Figure1. Theoretical and empirical framework

Model I: $\quad R O A_{i, t}=\beta_{0}+\beta_{1} M O_{i t-1}+\beta_{2}$ Control $+\varepsilon_{i t}$

(1)

Control represents control variables TOP1, TOP10, CFO, LEV, QR, Operate, SIZE, TAT, and EPS, to explain the reference control variable in detail shown in Table 1.

\begin{tabular}{l|l}
\hline Model II: & $R O A_{i, t}=\beta_{0}+\beta_{1} G M O_{i t-1}+\beta_{2}$ Control $+\varepsilon_{i t}$ \\
\hline
\end{tabular} 
ROA represents net interest rate of the total assets of public sector companies on behalf of GMO executive's shareholding, including public control samples. These are control variables such as TOP1, CFO, LEV, TOP10, QR, Operate, SIZE, TAT, EPS and their estimations are based on the model I.

\begin{tabular}{|l|l|l|}
\hline Model III: & $R O A_{i, t}=\beta_{0}+\beta_{1} F M O_{i t-1}+\beta_{2}$ Control $+\varepsilon_{i t}$ & (3) \\
\hline
\end{tabular}

ROA represents the net interest rate of total assets of non-state owned sector companies. FMO represents the proportion of executives in non-state owned sector companies. Control variables include
TOP1, TOP10, CFO, LEV, QR, Operate, SIZE, TAT and the explanation with their calculations of control variables based on model II.

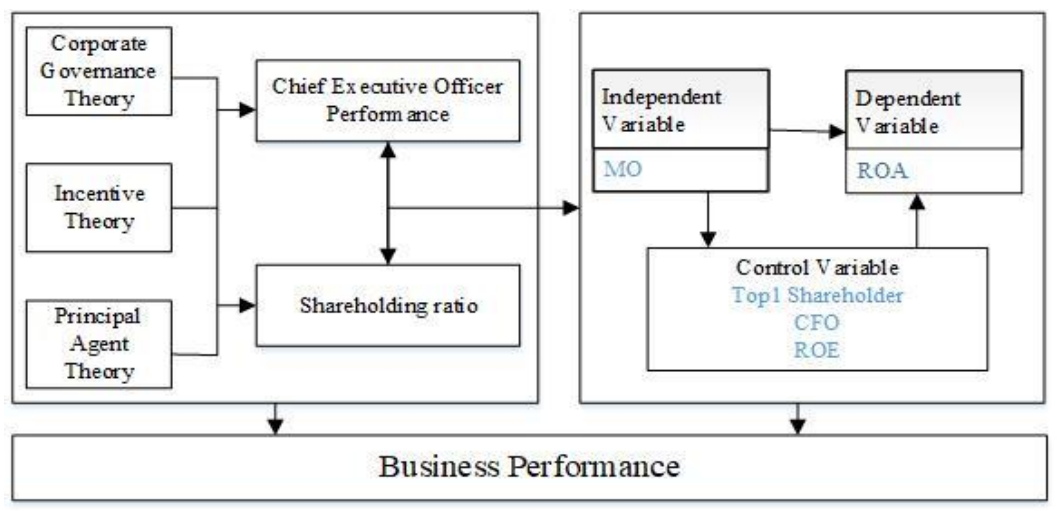

\section{RESULTS AND ANALYSIS Descriptive statistics}

Table 2 shows the dependent variable ROA is approximately 8.6 and the standard deviation is relatively high $(8.421 \%)$, which indicates ROA for listed companies is high. Average of MO is $37.312 \%$, which shows a common phenomenon of executive stock ownership in the Chinese listed companies. Corporate equity incentive with a standard deviation of 39.419 indicate those companies which are under the category of listed companies and with big difference of stock ownership in each enterprise. Some enterprises have no executives like minimum zero and relatively high proportion of shareholding such as $216.41 \%$.

Table-2: Descriptive statistics of the total sample

\begin{tabular}{|c|c|c|c|c|c|}
\hline Variable Name & Observed value & Mean standard & Deviation & Minimum & Maximum \\
\hline ROA & 185 & 8.6 & 8.421 & -23.95 & 61.81 \\
\hline M0 & 185 & 37.312 & 39.419 & 0 & 216.41 \\
\hline TOP1 & 174 & 28.011 & 12.315 & 7.813 & 60.61 \\
\hline TOP10 & 163 & 56.859 & 13.829 & 19.41 & 86.32 \\
\hline CFO & 181 & 73.23 & 219.3 & -576.82 & 940.92 \\
\hline LEV & 185 & 31.37 & 17.902 & 4.09 & 85.91 \\
\hline QR & 185 & 3.128 & 3.151 & 0.366 & 23.31 \\
\hline Operate & 185 & 6.148 & 2.8 & 0.772 & 9.15 \\
\hline SIZE & 185 & 22.311 & 1.023 & 14.593 & 24.16 \\
\hline TAT & 174 & 0.705 & 1.22 & 0.013 & 12.37 \\
\hline EPS & 174 & 0.477 & 0.590 & -1.71 & 2.22 \\
\hline
\end{tabular}

In the control variables, TOP 1 is calculated $28.011 \%$, while minimum and maximum value of the largest shareholder ratio is approximately $7.813 \%$ and $60.61 \%$, respectively. The average share of TOP 10 shareholders is $56.859 \%$ compared with proportion of the first largest shareholder and top ten shareholders is more than half shares. $\mathrm{CFO}$ is generated through operating activities is approximately $73.23 \%$, which indicates business income could increase by the good sales. Further, standard deviation is up to 219.3 , which shows a great difference between the conversions of business income into the cash flow of enterprises. The average value of LEV is $31.37 \%$ indicating assets and liabilities ratio of the Chinese listed companies is relatively low and contain small ratio of debt. The standard deviation is 17.902 shows less liabilities ratio of $85.91 \%$. The average of QR is 3.128 , which is higher than the mean range of normal industry. The variance is relatively small, which indicates companies could generate enough assets to repay debts and risk chances are relatively small. The control variable Operate transpires average of the operating cycle of the enterprise in 6.148 years indicating the recovery of the enterprises are slow and may affect the funds required for the normal turnover of the enterprises. The average size of the enterprise (SIZE) is 22.311, while the 
maximum and minimum values are 24.16 and 14.593 , respectively. However, difference is small and the standard deviation is 1.023 . The average value of TAT is 0.705 , whereas the standard deviation is 1.22 , rendering companies are faster and ability of operating the business is better. The average value of EPS in the selected listed companies is 0.477 , with a variance of 0.590 , which indicates the stock returns are good. The selected company's EPS rate of change is relatively small, which means the difference of the income level between companies is relatively small.

\section{Comparative analysis of listed companies}

Table 3 shows the comparative analysis of descriptive statistics between SOC and N-SOC of listed companies in China. In the explanatory/dependent variables, mean value of the total asset yield N-SOC is obviously higher than SOC. Moreover, standard deviation of SOC and N-SOC is approximately 5.523 and 9.063 , respectively. Since, standard deviation is relatively small due to the high profit. However, management efficiency of the N-SOC is better and market indicated accuracy.

Table-3: Descriptive statistics of SOC and N-SOC

\begin{tabular}{|c|c|c|c|c|c|c|c|c|c|c|c|c|}
\hline & Companies & ROA & M0 & TOP1 & TOP10 & CFO & LEV & QR & Operate & SIZE & TAT & EPS \\
\hline \multirow[t]{2}{*}{ Mean } & SOC & 5.523 & 2.915 & 36.436 & 52.645 & 137.298 & 39.098 & 2.471 & 5.532 & 22.425 & 1.013 & 0.767 \\
\hline & N-SOC & 9.063 & 42.914 & 27.397 & 57.253 & 92.567 & 33.602 & 3.737 & 5.698 & 21.649 & 1.18 & 1.003 \\
\hline \multirow{2}{*}{$\begin{array}{l}\text { Standard } \\
\text { deviation }\end{array}$} & SOC & 4.56 & 4.31 & 13.994 & 13.303 & 218.219 & 14.695 & 1.901 & 1.226 & 1.642 & 0.848 & 0.952 \\
\hline & $\mathrm{N}-\mathrm{SOC}$ & 9.057 & 40.252 & 12.447 & 14.577 & 306.708 & 17.292 & 3.777 & 1.617 & 1.562 & 1.558 & 1.016 \\
\hline \multirow{2}{*}{$\begin{array}{l}\text { Minimum } \\
\text { value }\end{array}$} & SOC & -1.99 & 0.34 & 12.57 & 23.01 & -187.06 & 18.08 & 0.88 & 4.31 & 20.19 & 0.55 & 0.26 \\
\hline & $\mathrm{N}-\mathrm{SOC}$ & -25.51 & 0.46 & 8.65 & 21.95 & -559.07 & 4.42 & 0.8 & 1.16 & 16.03 & 0.45 & -1.17 \\
\hline \multirow{2}{*}{$\begin{array}{l}\text { The } \\
\text { maximum } \\
\text { value }\end{array}$} & SOC & 15.53 & 11.56 & 56.24 & 72.92 & 819.69 & 63.25 & 7.09 & 7.49 & 24.5 & 2.15 & 2.27 \\
\hline & N-SOC & 60.34 & 207.01 & 63.17 & 83.95 & 2525.63 & 84.78 & 21.84 & 8.98 & 24.08 & 12.9 & 2.82 \\
\hline \multirow{2}{*}{$\begin{array}{l}\text { Sample } \\
\text { size }\end{array}$} & SOC & 25 & 24 & 24 & 24 & 25 & 25 & 25 & 25 & 25 & 25 & 25 \\
\hline & N-SOC & 173 & 143 & 165 & 145 & 172 & 173 & 173 & 173 & 173 & 173 & 173 \\
\hline
\end{tabular}

Independent variables show the difference in proportion of executive stock ownership is relatively large, while average share of SOC is $2.915 \%$, and the standard deviation is 4.31 . Executive shareholding ratio in SOC is relatively small, and the difference between companies is small. Whereas, executive shareholding average is approximately $42.914 \%$ in N-SOC. Furthermore, standard deviation is 40.252 , which shows proportion of $\mathrm{N}$-SOC is relatively high, and the difference between companies is larger than the SOC. Hence, shareholding ratio of the SOC is lower than NSOC. In the perspective of maximum and minimum proportion of executives, it can be inferred that proportion of $\mathrm{N}-\mathrm{SOC}$ is much higher than SOC. Largest shareholding ratio of SOC is higher than N-SOC. The average value of SOC is $36.436 \%$, while the maximum and minimum are $56.24 \%$ and $12.57 \%$, respectively. This shows SOC as the first large shareholder and have absolute control on company. In N-SOC, maximum value is calculated $63.17 \%$ and the minimum value is $8.65 \%$. The average mean $(27.397 \%)$ shows $\mathrm{N}-\mathrm{SOC}$ have the lower equity concentration than SOC. The proportion of top ten shareholders show the average of the SOC is 52.645 and average value of N-SOC is 57.253. It can be observed that the proportion of ownership concentration of the top ten shareholders of SOC and N-SOC is same, while the maximum and minimum also draw the same conclusion. LEV of SOC $(39.093 \%)$ is higher than N-SOC (33.602\%).

\section{Correlation analysis}

\section{Autocorrelation test of the total sample}

Table 4 shows autocorrelation test of total sample, wherein ROA and MO are significant at 5\% level. ROA, TOP10, Operate, SIZE and EPS are significant at the $1 \%$ level. ROA, LEV and TAT are significant at the level of $10 \%$. However, the remaining control variables are not significant with ROA. Although, coefficient between the control variables is significant due to the absolute value is less than 0.3 , which means sample of firm's data tends to expedite a serious multiple co-linearity.

Table-4: Total sample autocorrelation test

\begin{tabular}{|c|c|c|c|c|c|c|c|c|c|c|c|}
\hline Variables & ROA & MO & TOP1 & TOP10 & CFO & LEV & QR & Operate & SIZE & TAT & EPS \\
\hline ROA & 1 & & & & & & & & & & \\
\hline MO & $0.203^{* *}$ & 1 & & & & & & & & & \\
\hline TOP1 & 0.112 & $0.194 * *$ & 1 & & & & & & & & \\
\hline TOP10 & $0.298 * * *$ & $0.442 * * *$ & $0.493 * * *$ & 1 & & & & & & & \\
\hline $\mathrm{CFO}$ & 0.077 & -0.055 & 0.021 & -0.056 & 1 & & & & & & \\
\hline LEV & $-0.139 *$ & $-0.249 * * *$ & -0.026 & $-0.227 * * *$ & $0.168^{* *}$ & 1 & & & & & \\
\hline QR & 0.09 & $0.161 *$ & 0.141 & $0.189^{* * *}$ & $-0.141^{*}$ & $-0.624 * * *$ & 1 & & & & \\
\hline Operate & $-0.314 * * *$ & 0 & -0.059 & -0.102 & 0.024 & 0.124 & $-0.102 * * *$ & 1 & & & \\
\hline SIZE & $-0.251 * * *$ & $-0.252 * * *$ & -0.091 & $-0.224 * * *$ & 0.120 & $0.222 * * *$ & $-0.346 * * *$ & -0.019 & 1 & & \\
\hline TAT & $-0.127 *$ & -0.089 & -0.031 & -0.07 & -0.023 & $0.356^{* * *}$ & -0.134 & $-0.330 * * *$ & -0.034 & 1 & \\
\hline EPS & $0.615 * * *$ & $0.331 * * *$ & $0.228 * * *$ & $0.368 * * *$ & 0.134 & -0.098 & 0.53 & $-0.310 * * *$ & -0.053 & $-0.272 * * *$ & \\
\hline
\end{tabular}

Note: $* * *, * *, *$ is marked at the $1 \%, 5 \%$, and $10 \%$ levels respectively. 
Moreover, MO is positively related with ROA, and net interest rate of total assets is significant at the $5 \%$ level producing preliminary evidence of correlation exist between them. Executive holdings, largest shareholder holding ratio and quick ratio is significant at 5\%. However, correlation coefficient is small and there is no serious multiple co-linearity. Executive shareholding is significantly higher among control variables such as TOP10, LEV, Size and EPS at $1 \%$ level. Most of the correlation coefficients are less than
0.4 , which indicates no serious problem of multiple colinearity.

\section{Self-correlation test of SOC}

Table 5 shows GMO and ROA of SOC are not significant, which indicate SOC's executive having less effect on corporate performance. Since, most of the data between the control variables are not significant, and control variables are significant that resulted a small correlation coefficient. Hence, there is no serious multiple co-linearity.

Table-5: Autocorrelation test of the SOC

\begin{tabular}{|c|c|c|c|c|c|c|c|c|c|c|c|}
\hline Variables & ROA & GM0 & TOP1 & TOP10 & CFO & LEV & QR & Operate & SIZE & TAT & EPS \\
\hline $\mathrm{ROA}$ & 1 & & & & & & & & & & \\
\hline GM0 & 0.164 & 1 & & & & & & & & & \\
\hline TOP1 & 0.251 & -0.256 & 1 & & & & & & & & \\
\hline TOP10 & 0.32 & 0.19 & $0.920 * * *$ & 1 & & & & & & & \\
\hline $\mathrm{CFO}$ & 0.326 & 0.050 & -0.0334 & -0.209 & 1 & & & & & & \\
\hline LEV & 0.052 & 0.233 & 0.338 & 0.436 & 0.225 & 1 & & & & & \\
\hline QR & 0.081 & -0.137 & -0.274 & -0.115 & -0.022 & $-0.724 * * *$ & 1 & & & & \\
\hline Operate & -0.321 & 0.205 & -0.022 & -0.047 & -0.127 & 0.419 & $-0.597 * * *$ & 1 & & & \\
\hline SIZE & 0.289 & 0.142 & -0.085 & -0.125 & 0.261 & -0.131 & 0.148 & -0.234 & 1 & & \\
\hline TAT & 0.377 & 0.227 & $0.485^{* *}$ & $0.598 * * *$ & 0.067 & $0.528 * *$ & $-0.329 *$ & -0.227 & -0.091 & 1 & \\
\hline EPS & $0.894 * * *$ & 0.124 & 0.379 & $0.415^{*}$ & 0.133 & 0.112 & 0.069 & -0.490 & $0.451 *$ & $0.462 *$ & \\
\hline
\end{tabular}

Note: $* * *, * *, *$ is marked at the $1 \%, 5 \%$, and $10 \%$ levels respectively

\section{Self-correlation test of N-SOC}

Table 6 shows net interest rate of the total assets and executive holding of N-SOC are significant at $10 \%$ level. This significant level affecting a positive correlation and executive stock ownership has positive impact on corporate performance. There is a significant relationship of between control variables such as absolute value of correlation coefficient is less than 0.6.
Hence, numerical comparison is small and there is no serious multiple co-linearity. In addition, this simple correlation analysis transpires that controlling these control variables is effective but the results of the hypothetical verification are still uncertain. This uncertainty is yet required a specific explanation using multiple linear regression.

Table-6: Autocorrelation test of the N-SOC

\begin{tabular}{|c|c|c|c|c|c|c|c|c|c|c|c|}
\hline Variables & ROA & FMO & TOP1 & TOP0 & CFO & LEV & QR & Operate & SIZE & TAT & EPS \\
\hline ROA & 1 & & & & & & & & & & \\
\hline FM0 & $0.147 *$ & 1 & & & & & & & & & \\
\hline TOP1 & 0.139 & $0.335^{* * * *}$ & 1 & & & & & & & & \\
\hline TOP10 & $0.334 * * *$ & $0.426^{* * * *}$ & $0.639 * * *$ & 1 & & & & & & & \\
\hline $\mathrm{CFO}$ & 0.048 & -0.052 & -0.053 & -0.231 & 1 & & & & & & \\
\hline LEV & -0.138 & $-0.265 * * *$ & -0.101 & $-0.243 * * *$ & 0.138 & 1 & & & & & \\
\hline QR & 0.109 & 0.233 & $0.179 * *$ & $0.207 * *$ & -0.165 & $-0.644 * * *$ & 1 & & & & \\
\hline Operate & $-0.341 * * *$ & 0.021 & -0.076 & -0.232 & 0.064 & 0.141 & $-0.126^{*}$ & 1 & & & \\
\hline SIZE & $-0.321 * * *$ & $-0.235^{* *}$ & $-0.158^{* *}$ & $-0.222 * *$ & 0.054 & $0.251 * * *$ & $-0.334 * * *$ & -0.032 & 1 & & \\
\hline TAT & $-0.135^{*}$ & -0.089 & -0.021 & -0.074 & -0.024 & $0.388^{*} * *$ & -0.19 & $-0.324 * * *$ & -0.054 & 1 & \\
\hline EPS & $0.659 * * *$ & $0.377 * * *$ & $0.260 * * *$ & $0.367 * * *$ & 0.024 & -0.047 & 0.148 & $-0.343 * * *$ & -0.202 & $-0.256 * * *$ & \\
\hline
\end{tabular}

Note: $* * *, * * *$ is marked at the $1 \%, 5 \%$, and $10 \%$ levels respectively.

\section{Regression analysis of empirical samples}

The correlation test was conducted between dependent, independent and the control variable, which is a simple way to analyze and explain correlation between variables. In order to verify the results in accordance with afore-mentioned hypothesis, we adopted linear regression analysis method. This method can verify the research hypothesis of underlying measurement models and their results based on linear regression analysis are shown in Table 7. 
Table-7: Model I regression results

\begin{tabular}{|c|c|c|}
\hline $\begin{array}{l}\text { Variable } \\
\text { name }\end{array}$ & $\begin{array}{l}\text { (1) } \\
\text { No control variables are added } \\
\text { Dependent variable: ROA }\end{array}$ & $\begin{array}{l}\quad(2) \\
\text { Add control variables } \\
\text { Dependent variable: } \text { ROA }\end{array}$ \\
\hline MO & $\begin{array}{c}0.0414 * \\
(3.10)\end{array}$ & $\begin{array}{l}0.0298 * * \\
(2.76)\end{array}$ \\
\hline TOP1 & & $\begin{array}{l}-0.134^{*} \\
(-2.63) \\
\end{array}$ \\
\hline TOP10 & & $\begin{array}{l}0.1401 \\
(3.15)\end{array}$ \\
\hline $\mathrm{CFO}$ & & $\begin{array}{l}0.03570 \\
(1.51)\end{array}$ \\
\hline LEV & & $\begin{array}{l}0.0361 \\
(0.41)\end{array}$ \\
\hline $\mathrm{QR}$ & & $\begin{array}{l}-0.0621 \\
(-0.44)\end{array}$ \\
\hline Operate & & $\begin{array}{l}-1.367^{*} \\
(-2.61) \\
\end{array}$ \\
\hline SIZE & & $\begin{array}{l}-1.870 * * * * \\
(-3.31)\end{array}$ \\
\hline TAT & & $\begin{array}{l}-0.483 \\
(-0.93) \\
\end{array}$ \\
\hline EPS & & $\begin{array}{l}12.08 * * * \\
(9.100)\end{array}$ \\
\hline _cons & $\begin{array}{l}\text { 5.952*** } \\
(6.28)\end{array}$ & $\begin{array}{l}50.63 * * * \\
(3.79) \\
\end{array}$ \\
\hline $\mathrm{N}$ & 165 & 161 \\
\hline
\end{tabular}

In the regression model I (1), results based on regression analysis between $\mathrm{MO}$ and ROA of the total assets transpired positive correlation with corporate performance and significant level of $10 \%$ shows executive shareholding ratio could increase the performance of the business. In the regression model I (2), selected control variables are added indicating executive shareholding ratio MO and net interest rate of ROA is positive and significant at 5\% level. Hence, executive stock ownership of the Chinese listed companies are beneficial and corporate performance is also increased. This validates research hypothesis (H1).

Among the control variables, there is a negative correlation between ROA and TOP1 are significant at $10 \%$ level. Thereby, high proportions of shareholder may affect and worsen the performance of company leveraging largest shareholder with greater decision-making power imposing damage to the interests of the company. Operate signifies negative correlation with net interest rate of the total assets of the enterprise and is significant at the level of $10 \%$. This shows longer the operating period of the company, the less improvement of the company performance. Meanwhile, enterprise could possibly endeavor to reduce the company business cycle and speed up the business turnover rate. The company size has a negative correlation with the enterprise performance and is significant at the $1 \%$ level. The results suggested company size must not be bigger and size of the company must be reduced in order to improve the business performance. Hence, executive discretion shows negative correlation with corporate performance in Chinese listed companies and validates research hypothesis (H2). EPS and gross margin of total assets is a positively correlated, and it is significant at the $1 \%$ level. This indicates the increase in earnings per share representing better performance of the company and validate the research hypothesis ( $\mathrm{H} 3$ and $\mathrm{H} 4)$.

State-owned executive stock ownership and corporate performance regression analysis

Table 8 shows results of Model II regression analysis of SOC and adopted the stepwise method to verify the research hypothesis. In regression model II (3), no control variables are added. Moreover, regression results showed GMO coefficient is 0.232 and reaction was $\mathrm{T}$ value at 0.69 . However, relationship between shareholding ratio of SOC (as an independent variable) and net interest rate of the total assets (as a dependent variable) is not significant. This shows executive stock ownership on corporate performance has no obvious effect. Thereby, validating the hypothesis H3 and H4. In regression model II (4), regression results are not significant when the control variables are added. Further, results transpire relationship between the proportion of executive stock ownership and enterprise performance is not significant. Hence, increment in executive stock ownership of SOC has no significant impact on corporate performance. Thereby, validating the hypothesis $\mathrm{H} 3$ and $\mathrm{H} 4$. 
Table-8: Model II Regression results

\begin{tabular}{|c|c|c|}
\hline $\begin{array}{c}\text { Variable } \\
\text { name }\end{array}$ & $\begin{array}{l}\quad(3) \\
\text { No control variable } \\
\text { Dependent variable: } \\
\text { ROA }\end{array}$ & $\begin{array}{l}\quad \text { (4) } \\
\text { Adding control } \\
\text { variables } \\
\text { Dependent variable: } \\
\text { ROA }\end{array}$ \\
\hline GMO & $\begin{array}{c}0.232 \\
(0.69)\end{array}$ & $\begin{array}{l}0.287 \\
(0.150)\end{array}$ \\
\hline TOP1 & & $\begin{array}{l}-0.0533 \\
(-0.26)\end{array}$ \\
\hline TOP10 & & $\begin{array}{l}0.0699 \\
(0.38)\end{array}$ \\
\hline $\mathrm{CFO}$ & & $\begin{array}{l}-0.01038 \\
(-1.418)\end{array}$ \\
\hline LEV & & $\begin{array}{l}-0.1153 \\
(-1.223)\end{array}$ \\
\hline QR & & $\begin{array}{c}-2.138 \\
(-1.352)\end{array}$ \\
\hline Operate & & $\begin{array}{l}-5.047 \\
(-2.89) \\
\end{array}$ \\
\hline SIZE & & $\begin{array}{l}-0.7448 \\
(-0.87)\end{array}$ \\
\hline TAT & & $\begin{array}{l}-4.4942 \\
(-1.4002)\end{array}$ \\
\hline EPS & & $\begin{array}{c}8.1353 \\
(2.232) \\
\end{array}$ \\
\hline _cons & $\begin{array}{l}5.201 * * \\
(3.50)\end{array}$ & $\begin{array}{l}56.44 \\
(1.59)\end{array}$ \\
\hline $\mathrm{N}$ & 25 & 25 \\
\hline
\end{tabular}

\section{Non-state owned executive stock ownership and corporate performance regression analysis}

Table 9 shows the result analysis of the regression model II of $\mathrm{N}-\mathrm{SOC}$, a gradual approach to verify research hypothesis. In the regression model II (5), no control variables are added, wherein the correlation coefficient of shareholding ratio is 0.12114 and is significant at the level of $10 \%$. Results shows executive ownership of N-SOC is beneficial and corporate performance is increased. Hence, validates the hypothesis (H1). In regression model II (6), results shows coefficient of the executive shareholding ratio is 0.0485 at $5 \%$ significant level with the inclusion of control variables. Moreover, control variables significantly increased the saliency. Executive stock ownership has more explanatory power that could increase corporate performance and hence is validating hypothesis (H1). Furthermore, proportion of the first larger shareholder and proportion of the top ten shareholders are significant at the level of $10 \%$. Meanwhile, impact on corporate performance is the opposite. The correlation coefficient of the proportion of the first large shareholders is -0.1230 , which shows opposite results with the moderate increase in enterprise performance. The correlation coefficient between the top ten shareholders is 0.302 , which shows same result for impulsive increase of business performance due to the number of shareholders plays a counterbalance in the process of decisions making of the company. 
Table-9: Model II (2) Regression results

\begin{tabular}{|c|l|l|}
\hline Variable name & $\begin{array}{l}\text { No control variable(5) } \\
\text { Dependent variable: ROA }\end{array}$ & $\begin{array}{l}\text { Adding control variables(6) } \\
\text { Dependent variable: ROA }\end{array}$ \\
\hline FMO & $\begin{array}{l}0.12114^{*} \\
(2.281)\end{array}$ & $\begin{array}{l}0.0485^{* *} \\
(2.73)\end{array}$ \\
\hline TOP1 & & $\begin{array}{l}-0.1230^{*} \\
(-1.66)\end{array}$ \\
\hline TOP10 & & $\begin{array}{l}0.302^{*} \\
(2.023)\end{array}$ \\
\hline CFO & & $\begin{array}{l}0.00258 \\
(1.17)\end{array}$ \\
\hline LEV & & $\begin{array}{l}0.0291 \\
(0.44)\end{array}$ \\
\hline QR & & $\begin{array}{l}-0.0329 \\
(-0.356)\end{array}$ \\
\hline Operate & & $\begin{array}{l}-1.2221 * \\
(-2.021)\end{array}$ \\
\hline SIZE & & $\begin{array}{l}-2.0185^{* *} \\
(-3.17)\end{array}$ \\
\hline TAT & & $\begin{array}{l}-0.3530 \\
(-0.512)\end{array}$ \\
\hline EPS & & $\begin{array}{l}13.363 * * \\
(7.43)\end{array}$ \\
\hline cons & & $\begin{array}{l}48.60 * * \\
(3.35)\end{array}$ \\
\hline N & & 161 \\
\hline Note: $* * *, * *$ & $*$ is marked at the $1 \%, 5 \%$, and $10 \%$ levels respectively. \\
\hline
\end{tabular}

Regression analysis results in Table 8 and 9 shows total sample was divided into SOC and N-SOC with and without the inclusion of control variables in the regression model I and II. In SOC, executive ownership is conducive while increasing the corporate performance, whereas influence of executive ownership is beneficial for increasing corporate performance in $\mathrm{N}$ SOC. In addition, state-owned executive shareholding has no significant impact on business performance, while the impact of executive ownership on firm performance is significant in N-SOC. Executive ownership of SOC appeared less influence on corporate performance in comparison to N-SOC, which transpired influence of executive ownership on corporate performance is significant.

\section{Robustness test}

Robustness test is conducted to describe underlying proposed model I and II and verifying improvised hypothesis. The validity of net interest rate of total assets of company is taken into consideration as a measurement of corporate performance. The robustness test results are as shown in Table 10 . Moreover, results show the Model I is the robustness test for the total samples of SOC. The standard coefficient of the proportion of executive and net asset returns is 0.0547 , which is significant at the $5 \%$ level and indicates a positive correlation. Meanwhile, executive ownership plays a positive role in promoting corporate performance, that is, hypothesis $(\mathrm{H} 1)$ is verified. The standard coefficient of executive shareholding ratio and net assets is approximately 0.1240 , which is significant at the $5 \%$ level and shows a positive correlation. This indicates that executive shareholding of $\mathrm{N}$-SOC has a positive effect on corporate performance and hence verify the hypothesis (H1 and $\mathrm{H} 3$ ). 
Table-10: Robustness regression results

\begin{tabular}{|l|l|l|}
\hline Variable name & $\begin{array}{l}\text { Model 1 } \\
\text { Dependent variable: ROE }\end{array}$ & $\begin{array}{l}\text { Model 2 } \\
\text { Dependent variable: ROE }\end{array}$ \\
\hline MO & $0.0547^{* *}$ & $0.1240^{* *}$ \\
& $(3.021)$ & $(3.034)$ \\
\hline TOP1 & $-0.276^{*}$ & -2.151 \\
& $(-2.454)$ & $(-1.60)$ \\
\hline TOP10 & 0.336 & 0.337 \\
& $(1.81)$ & $(1.37)$ \\
\hline CFO & 0.00671 & 0.00668 \\
& $(0.901)$ & $(0.81)$ \\
\hline LEV & $0.254 * * *$ & $0.326 * * *$ \\
& $(3.72)$ & $(4.78)$ \\
\hline QR & -0.0349 & -0.0183 \\
& $(-0.17)$ & $(-0.14)$ \\
\hline Operate & $-2.424 *$ & $-2.422^{*}$ \\
& $(-2.69)$ & $(-2.656)$ \\
\hline SIZE & $-3.938^{* * *}$ & $-4.109 * * *$ \\
& $(-4.77)$ & $(-3.99)$ \\
\hline TAT & $-6.1991^{* * *}$ & $-6.235^{* * *}$ \\
& $(-6.280)$ & $(-5.81)$ \\
\hline EPS & $20.71 * * *$ & $20.210^{* * *}$ \\
& $(8.387)$ & $(7.419)$ \\
\hline cons & $92.488^{* * *}$ & $93.091 * * *$ \\
& $(4.243)$ & $(3.95)$ \\
\hline N & 165 & 161 \\
\hline
\end{tabular}

Note: $* * *, * *, *$ is marked at the $1 \%, 5 \%$, and $10 \%$ levels respectively and the value in the parenthesis is the $\mathrm{T}$ value of the corresponding coefficient.

\section{CONCLUSION AND DISCUSSION}

Executive shareholding ratio is a measurement index of executive shareholding effectiveness. In this paper, we present an empirical analysis which deemed to investigate the relationship between executive ownership and corporate performance. In addition, there is a causal relationship between executive and corporate performance, wherein management is affected due to an incentive for executive ownership. In the regression model I, analysis carried between executive ownership and corporate performance that mainly shows the incentive function of the executive stock by means of incentive; thus giving an equity incentive towards executives and improved the corporate performance as well. Moreover, regression analysis is induced which shows that executive ownership helps to monitor and motivate management to align the interests of executives and shareholders, thereby reducing the shortterm behavior of senior executives and improved the corporate performance too.

In the regression model II, results based on SOC exploited that the executive are not significant towards the performance of the company, that is, executive shareholding deemed as an incentive means has poor effect on corporate performance. In SOC, largest shareholder of the company has absolute control over the company. The entire company's management operation, Chairman and general manager are in the vertex position expediting the decisive influence on the company's survival and development. Moreover, managers occupy a relatively small number of shares in the company, that is, with minimum or less amount of shares resulting the executive stock without a significant impact on corporate performance. In the model II, results based on Non-SOC resembles that the executive stock ownership has positive significance to the performance of the enterprise. When non-stateowned enterprises are motivated through equity and pay more attention in order to influence executive shareholding via efficiency, coverage and equity of shareholding between executives. Results also shows the performance of N-SOC is higher than SOC.

\section{Implications and countermeasures}

Our investigation suggested the improvement of the company's performance appropriately and enhanced the proportion of managers' shareholding. At present, Chinese listed companies evolved with lower share of average value due to some of them do not use executive holding. Our findings suggested advancement of proportion of senior executives resulting dual status of management and shareholders. Moreover, interests of shareholders could promote management efforts in order to improve the performance of enterprises for further coverage. At the same time, improving corporate performance through increasing the value of enterprises to generate better benefits toward shareholders. However, several aspects such as to pay attention to the adverse effects of the higher shareholding ratio and excessive shareholding that could turn executives out of 
the shareholder interests into their own interests, and thus damaging interests of the company and shareholders. In addition, enterprise should reasonably control the investment expenditure that could accelerate a negative impact on the business. Since, risk and income are directly related to each other in the investment, whereas the high income could cause high risk. In accordance with the rapid growth of enterprises, investment is not the only factor necessarily tends to worsen the performances, while disregard of risk may damage the interests of the company. Thereby, enterprise investment deportment can be recognized with the stock market in order to mark up the positive impact in the development of the enterprise, which is accomplished through ability to resist risk, maintaining a moderate investment scale with a relatively optimal capital structure, and sustaining a certain amount of liquidity. Consciousness to the performance of the company is an in-depth assessment of the company performance and balanced governance. Different companies could not generalize comprehensive consideration to executive ownership and investment behavior, which affected the corporate performance and the size of the company [59].

\section{Limitation and future research}

The study of management ownership is considered to unify management into undifferentiated individuals. In reality, management of the company could influence the amount and time of ownership because of the different identity background and knowledge experience, and difference of managers' investment concept might affect the decision of their shareholding. In addition, the position and the power size of management in the board of directors could also affect the decision-making. Therefore, research is expected to infer and consider the level of management and investment trends in future work.

The selected samples of the listed companies are analyzed only and simply explained the characteristics of the selected samples. Conversely, different industry management shares and corporate performance could possibly affect the relationship that may bring lot of changes in accordance with present research. Meanwhile, company's main business is different because of the different nature of the industry considering the major income and main cash flow. These factors could affect the company's financial performance in different stages. In the future research, correlation between executive holding and corporate performance in the background of different industries is suggested to improve corporate performance.

The investment behavior is selected in this article could not distinguish between the different investment projects. Cash flow generated by the company's investment activities in the fiscal year, and corresponding corporate financial performance is also accounted at end of the fiscal year. Our findings in the present research were restricted to consider a unified quantitative analysis of investment behavior and hence do not consider the different nature of investment projects. For example, some investment projects with short payback period and quick results may increase the earnings of enterprises in the year. Thereby, improving the performance of the company. Whereas, company is conducive in a long-term development and some investment projects might not be able to obtain a larger income in a shorter period in perspective of sustainable development of the company. Therefore, inclusion of fine-grained branch of investment projects is preferred to obtain accurate analysis in both theoretical and empirical methods. Eventually, present investigation study distinguishes the sources and types of different management shares and further discusses the influence of structural factors on the performance of the company. Subdividing or adjusting the index and re-model our improvised analysis could be interesting discovery for business performance.

\section{REFERENCES}

1. Alas, R., \& Elenurm, T.(2014). Corporate Governance Development in a Rapidly Changing Economy: Trends and Challenges in Estonia. In: Boubaker S., Nguyen D. (eds), Corporate Governance in Emerging Markets. CSR, Sustainability, Ethics \& Governance, Springer, Berlin, Heidelberg.

2. Azim, L. M. (2012). Corporate Governance Mechanisms and Their Impact on Company Performance: A Structural Equation Model Analysis, Australian Journal of Management, 37(3), 481-505, 2012.

3. Cumberland, D. M., \& Githens, R. P.(2014). Organization Development through Franchise Advisory Boards: A Model for Governance Relationships, Human Resource Development Review, 13(4), 437-461.

4. Li, W., Xu Y., Niu J., \& Qiu, A.(2012). A Survey of Corporate Governance: International Trends and China's Mode, Nankai Business Review International, 3(1), 4-30.

5. Wen, Y., Rwegasira, K., \& Bilderbeek, J. (2002). Corporate Governance and Capital Structure Decisions of the Chinese Listed Firms, Corporate Governance: An International Review, 10(2), 7583, 2002.

6. Zhou, H., Zhou, C., Lin, W., \& Li, G.(2017). Corporate governance and Credit Spreads on Corporate Bonds: An Empirical Study in the Context of China, China, Journal of Accounting Studies, 5(1), 50-72, 2017.

7. Bae, S. M., Masud, M. A. K., \& Dae, J.(2018). Kim A Cross-Country Investigation of Corporate Governance and Corporate Sustainability Disclosure: A Signaling Theory Perspective, Sustainability, 2611, 10(8), 1-16

8. Bonazzi, L., \& Islam, S. M. N. (2007). Agency Theory and Corporate Governance: A Study of the 
Effectiveness of Board in their Monitoring of the CEO, Journal of Modelling in Management, 2(1), 7-23

9. Mironov, M. (2015). Should One hire a Corrupt CEO in a Corrupt Country? Journal of Financial Economics, 117(1), 29-42.

10. Brunsson, N., Rasche, A., \& Seidl, D.(2012). The Dynamics of Standardization: Three Perspectives on Standards in Organization Studies, Organization Studies, 33(5-6), 613-632.

11. C-Cladera, R., \& P-Fuster, B.(2015). Executive Directors' Pay, Networks and Operating Performance: The Influence of Ownership Structure, Journal of Accounting and Public Policy, 34(2), 175-203, 2015

12. Tavana, M., Caprio, D. D., \& S-Arteaga F. J.(2016). Managing Team Coordination Incentives: The Effect of Payoff Differentials, Journal of Centrum Cathedra, 9(1), 52-70.

13. Guner, N., \& Parkhomenko, A., Ventura, G.(2018). Managers and Productivity Differences, Review of Economic Dynamics, 29, 256-282.

14. Tian, X., \& Slocum, J.W.(2016). Managing Corporate Social Responsibility in China, Organizational Dynamics, 45, 39-46.

15. Wilson, N., Wright, M., \& Kacer, M.(2018). The Equity Gap and Knowledge-based Firms, Journal of Corporate Finance, 50, 626-649.

16. Corporate Governance of Listed Companies in China: Self-Assessment by the China Securities Regulatory Commission, OECD-China Policy Dialogue on Corporate Governance, 2011. http://dx.doi.org/10.1787/9789264119208-en

17. State-Owned Assets Supervision and Administration Commission (SASAC). (2006). The Transition Guidelines of Operating Performance Evaluation of Persons in Charge of Central Government Supervised State-owned Enterprises. http://xxgk.

sasac.gov.cn/gips/contentSearch?id.7378982

18. Xiaoyan, T., \& Yujing, H.(2014). Study of Effects of Equity Incentive in Gem Listed Company. International Business and Management, 9(2), 8085.

19. Shao, L.(2018). Dynamic Study of Corporate Governance Structure and Firm Performance in China: Evidence from 2001-2015, Chinese Management Studies.

20. Ozkan, N. (2018). CEO Compensation and Firm Performance: An Empirical Investigation of UK Panel Data. European Financial Management, 17(2), 260-285.

21. Aasma, M., Zhang, Y., Muhammad, Q., Memon., \& Binbin, Y. (2019).. IT capability, capital availability and firm performance. Journal of Human Systems Management., 38(2019) 221-233,

22. Ciftci, I., Tatoglu, E., Wood, G., Demirbag, D., \& Zaim, S. (2019). Corporate Governance and Firm Performance in Emerging Markets: Evidence from
Turkey, International Business Review, 28(1), 90 103, 2019.

23. Gulen, H., \& O'Brien, W. J.(2017). Option repricing, Corporate Governance, and the Effect of Shareholder Empowerment, Journal of Financial Economics, 125(2), 389-415.

24. Müllera, R. J., \& Turner, R.(2005). The Impact of Principal-Agent Relationship and Contract Type on Communication between Project Owner and Manager, International Journal of Project Management, 23(5), 398-403.

25. Javeed, S. A., \& Lefen, L.(2019). An Analysis of Corporate Social Responsibility and Firm Performance with Moderating Effects of CEO Power and Ownership Structure: A Case Study of the Manufacturing Sector of Pakistan, Sustainability, 11(1), 248.

26. Krüger, P.(2018). Corporate Goodness and Shareholders Wealth, Journal of Financial Economics, 115(2):304-329.

27. Narayanan, J., Vikram, K. N., \& Harley, E. R. (2015). Does Combining the CEO and Chair Roles Cause Poor Firm Performance? Georgia Tech Scheller College of Business Research, 11, 53, 2015.

28. Yermack, D.(1996). Higher Market Valuation of Companies with a Small Board of Directors. Journal of Financial Economics, 40(2), 185-211.

29. Hill, W. L. C., \& Jones, T. M.(1992). StakeholderAgency Theory, Journal of Management Studies, 29(2)

30. Jensen, M., \& Meckling, W. (2011). Theory of the firm: Managerial Behavior, Agency Costs and Ownership Structure. Journal of Financial Economics, 3(4), 305-60.

31. Nyberg, A. J., \& Fulmer, I. S. (2011). Agency Theory Revisited: CEO Returns and Shareholder Interest Alignment, Academy of Management Journal, 53(5), 1029-1049.

32. Wang, S., \& Zhang, C.(2015). Effect of New CEO Power on Managerial Compensation Gap: A Conceptual Model. In: Qi E., Shen J., Dou R. (eds) Proceedings of the 21st International Conference on Industrial Engineering and Engineering Management 2014. Proceedings of the International Conference on Industrial Engineering and Engineering Management. Atlantis Press, Paris, 2015.

33. Rivera, T. J.(2018). Incentives and the Structure of Communication, Journal of Economic Theory, 175, $1-14$,

34. Oliver, R. L.(1974). Expectancy Theory Predictions of Salesmen's Performance. Journal of Marketing Research, 11(3), 243-253.

35. Huyghebaert, N., \& Wang, L.(2012). Expropriation of Minority Investors in Chinese Listed Firms: The Role of Internal and External Corporate Governance Mechanisms, Corporate Governance: An International Review, 20(3), 308-322. 
36. Wang, R., \& Yongbo, L.(2017). Incentive Mechanisms for Tacit Knowledge-Sharing in Master-Apprentice Pattern Based on the PrincipalAgent Theory. MATEC Web of Conferences, 100:05005.

37. Yusoff, W. F. W., Kian T. S., \& Idris M. T.M.(2013). Herzberg's Two Factors Theory on Work Motivation: Does its Work for Today's Environment? Global Journal of Commerce and Management Perspective, 2(5), 18-22.

38. Hur, Y.(2018). Testing Herzberg's Two-Factor Theory of Motivation in the Public Sector: Is it Applicable to Public Managers? Public Organization Review, 18(3), 329-343.

39. Mittelman, W.(2014). Maslow's Study of SelfActualization: A Reinterpretation, Journal of Humanistic Psychology, 31(1), 114-135.

40. Khan, A.(2016). Relationship of Internal Audit Quality and Corporate Governance Measures of Multinational Corporations (Mncs) of Pakistan, Sarhad Journal of Management Sciences, 2(1), 2523-2525.

41. Gurupdesh., Pandhera, S., Joseph, D. V.(2018). Divisional Managers' Compensation to Maximize Spillovers and Cooperation, International Review of Economics \& Finance, 54, 44-54.

42. Coleman, A. K., \& Biekpe, N.(2007). On the Determinants of Board Size \& its Composition: Additional evidence from Ghana, Journal of Accounting \& Organizational Change, 3(1), 68-77.

43. Jiang, F., Kim, K. A.(2015). Corporate Governance in China: A Modern Perspective, Journal of Corporate Finance, 32, 190-216, 2015.

44. Swami, S.(2013). Executive Functions and Decision Making: A Managerial Review, IIMB Management Review, 25(4), 203-21.

45. Shen, C-H., Luo, F., \& Huang, D.(2015). Analysis of Earnings Management Influence on the Investment Efficiency of Listed Chinese Companies, Journal of Empirical Finance, 34, 6078.

46. Gao, B., Chan, W. K., \& Li, H. (2015). On the increasing inequality in size distribution of China's listed companies, China Economic Review, 36, 2541.

47. Páez-Pérez, D., \& Sánchez-Silva, M. (2016). A Dynamic Principal-Agent Framework For Modeling The Performance of Infrastructure, European Journal of Operational Research, 254(2), 576-594

48. Ghosh, C., \& Sirmans, C. F.(2003). Board Independence, Ownership Structure and Performance: Evidence from Real Estate
Investment Trust, Journal of real estate finance and economics, 25(2-3), 287-318, 2003.

49. Lau, A., \& Vos, E.(2004). Relation between CEO Compensation, Firm Size and Firm Performance. Journal of Applied Business Research, 3(1), 51-64, 2004.

50. Bryson A., Forth J. and Zhou M., Who Posts Performance Bonds and Why? Evidence form China's CEOs, China Economic Review, 30, 520529.

51. Plockinger, M., Aschauer, E., Hiebl, M. R. W., \& Rohatschek, R. (2016). The Influence of Individual Executives on Corporate Financial Reporting: A Review and Outlook from the Perspective of Upper Echelons Theory, Journal of Accounting Literature, 37, 55-75.

52. Aasma, M., Zhang, Y., An., \& Muhammad, Q.M. (2019). Does financial availability sustain financial, innovative, and environmental performance? Relation via opportunity recognition. Journal of Corporate Social Responsibility and Environmental Management, 2019; 1-14. DOI: 10.1002/csr.1820

53. Shu, W., Chen, Y., Lin, B., \& Chen, Y.(2018). Does the Corporate Integrity Improve the Quality of Internal Control? China Journal of Accounting Research, 11(4), 407-427.

54. Demsetz, H., \& Villalonga, B. (2001). Ownership Structure and Corporate Performance. Journal of Corporate Finance, 7(3), 209-233.

55. Ozkan, N. (2007). Do Corporate Governance Mechanism Influence CEO Compensation? An Empirical Investigation of UK companies, Journal of Multinational Financial Management, 17, 349364.

56. Ferri, F., Zheng, R., \& Zou, Y. (2018). Uncertainty about Managers' Reporting Objectives and Investors' Response to Earnings Reports: Evidence from the 2006 executive Compensation Disclosures, Journal of Accounting and Economics, 66(2-3), 339-365.

57. Page, M., \& Spira, L. F. (2016). Special Issue on "Business Models, Financial Reporting and Corporate Governance, Journal of Management \& Governance, 20(2), 209-211.

58. Paniagua, J., Rivelles, R., \& Sapena, J. (2018). Corporate Governance and Financial Performance: The Role of Ownership and Board Structure, Journal of Business Research, 89, 229-234.

59. Vareska, V. D. V., Wim, V., \& Geert, D.(2011). Additivity and Complementarity in External Technology Sourcing: The Added Value of Corporate Venture Capital Investments, IEEE Transactions on Engineering Management, 58(3), 483-496. 